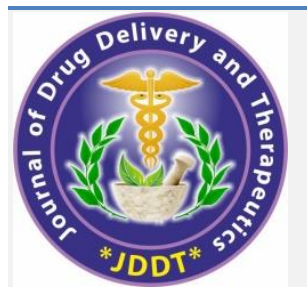

Open Access Full Text Article
Available online on 15.11.2021 at http://jddtonline.info

\section{Journal of Drug Delivery and Therapeutics}

Open Access to Pharmaceutical and Medical Research

Copyright (C) 2021 The Author(s): This is an open-access article distributed under the terms of the CC BY-NC 4.0 which permits unrestricted use, distribution, and reproduction in any medium for non-commercial use provided the original author and source are credited

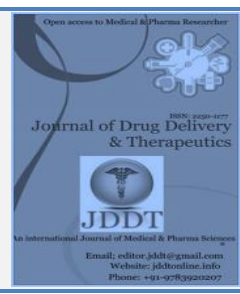

Review Article

\title{
Zarawand Mudharaj (Aristolochia rotunda Linn.), an important medicinal plant used in Unani system of medicine: A review
}

\author{
Athar Parvez Ansari ${ }^{*}$ (D), Huzaifa Ansari ${ }^{1}$, Tariq Ahmad Butt ${ }^{1}$, Ifra Qayoom ${ }^{1}$, N. Zaheer Ahmed ${ }^{2}$ \\ ${ }^{1}$ Regional Research Institute of Unani Medicine, Srinagar, Jammu \& Kashmir, CCRUM, Ministry of AYUSH, Govt. of India \\ ${ }^{2}$ Regional Research Institute of Unani Medicine, Chennai, CCRUM, Ministry of AYUSH, Govt. of India
}

Article Info:

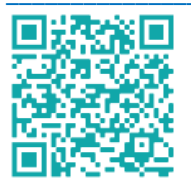

Article History:

Received 23 September 2021 Reviewed 30 October 2021

Accepted 07 November 2021

Published 15 November 2021

\section{Cite this article as:}

Ansari AP, Ansari H, Butt TA, Qayoom I, Ahmed NZ, Zarawand Mudharaj (Aristolochia rotunda Linn.), an important medicinal plant used in Unani system of medicine: A review, Journal of Drug Delivery and Therapeutics. 2021; 11(6):272-280

DOI: http://dx.doi.org/10.22270/jddt.v11i6.5072

\section{*Address for Correspondence:}

Athar Parvez Ansari, Regional Research Institute of Unani Medicine, University of Kashmir Naseembagh campus, Habak, Hazratbal, Srinagar Jammu \& Kashmir (190006), India

ORCID ID: https://orcid.org/0000-0002-5755-3525

\section{Abstract}

Background: Zarawand Mudharaj (Aristolochia rotunda L.) belongs to family Aristolochiaceae. According to Unani scholars, it is a female plant of Aristolochia fontanesii Boiss. \& Reut. (Syn. A. longa L.), usually found growing in Mediterranean regions, Central Asia and South Europe.

Purpose of the review: The main aim of this review is to highlight various aspects of Zarawand Mudharaj such as temperament, botanical description, pharmacological properties, therapeutic uses etc, as mentioned in Unani literature that will ultimately guide researchers to design various studies for further exploration of this important medicinal plant.

Materials and methods: The present review has been carried out through extensive literature survey of various classical Unani and botanical texts, and published papers available on different search engines. The botanical names and their synonyms were validated through 'The Plant List' (www.theplantlist.org).

Results: In Unani medicine, the rhizome of Zarawand Mudharaj is used for the treatment of several ailments viz. stomach and liver diseases, jaundice, cough, septic wounds, splenomegaly, gout etc. Apart from its use as single drug, it has also been added in many compound preparations viz. Anqarooya-i-Kabir, Habb-i-Rewand, Majun Falasifa, Majun Dabeedul Ward etc. A study on physicochemical standardization of rhizome of Aristolochia rotunda L. has reported the presence of moisture content, total ash, acid insoluble ash, water soluble ash, sulphated ash, alcohol and water-soluble extractive values within normal limits. The same study has also revealed that the hydro-alcoholic extract of rhizome of Aristolochia rotunda $\mathrm{L}$. possesses significant hepatoprotective activity against $\mathrm{CCl}_{4}$ induced liver toxicity in albino Wistar rats. Several toxicity reports have pointed out that aristolochic acid containing herbal drugs including Aristolochia rotunda L. cause renal impairment and other serious adverse reactions.

Conclusion: It is concluded that Aristolochia rotunda L. is widely used in Unani system of medicine. However, extensive studies on pharmacognosy, pharmacology, toxicology, phytochemistry and quality control of different parts of this potential medicinal plant have not been carried out so far. Therefore, such studies on modern scientific parameters may be conducted for further exploration so that the benefits may reach the masses.

Keywords: Zarawand Mudharaj; Aristolochia rotunda L.; Unani medicine; Hepatoprotective; Aristolochic acid; Toxicity

\section{Abbreviations:}

AAN: Aristolochic acid nephropathy; ALP: Alkaline Phosphatase; AYUSH: Ayurveda, Yoga and Naturopathy, Unani, Siddha and Homeopathy; BfArM: Bundesinstitutfür Arzneimittel und Medizinprodukte; CCl4: Carbon tetrachloride; CCRUM: Central Council for Research in Unani Medicine; IARC: International Agency for Research on Cancer; pH: Power of Hydrogen ion; RRIUM: Regional Research Institute of Unani Medicine; SGOT: Serum Glutamic Oxaloacetic Transaminase; SGPT: Serum GlutamatePyruvate Transaminase; USFDA: United States Food and Drug Administration; WHO: World Health Organization 


\section{INTRODUCTION:}

Aristolochia rotunda L. is a perennial herb belonging to the family Aristolochiaceae. The name of the genus Aristolochia originated from two Greek words 'aristos' and 'lochia' which means 'the best' and 'child birth', respectively and named on the basis of folklore use as uterine stimulants. Aristolochia rotunda L. predominantly grows along the banks of canals, edges of ditches and fields, sides of roads, meadows, slopes and forests preferably in chalky soils and moist, shady areas, at an altitude of $0-800$ meters above the sea level. ${ }^{1}$ In Unani medicine, Aristolochia rotunda L. is referred to as 'Zarawand Mudharaj' or 'Zarawand Gird' as mentioned in various classical texts such as Al-Jame al-Mufredat al-Adwiyava alAghzia of Ibn al-Betar', Al-Qanoon fi al-Tib of Ibn Sina ${ }^{3}$, Muheeta-i-Azam of Azam Khan', Khazain al-Adwiya of Najmul Ghani Khan etc. The meaning of 'mudharaj's or 'gird' is 'round' and refers to the shape of root of this plant. Ibn Sina (980-1037 AD) has mentioned that this is a female plant of Zarawand Taveel [(Aristolochia fontanesii Boiss. \& Reut. (Syn. A. longa L.) $]^{3}$, and is prescribed for the treatment of various ailments including inflammatory liver diseases, jaundice, gout 4,5 , and diseases of spleen. ${ }^{2}$ This medicinal plant is also used in other traditional systems of medicine in the treatment of chronic cough, bronchial asthma, pleurisy, amenorrhea, chronic pains, arthritis, sciatica, hepatitis, splenitis etc. ${ }^{6}$ In 1992, an increased prevalence of chronic renal failure associated with urothelial cancers in patients taking slimming pills contain plants of Aristolochia species 7,8 raised a global concern. After few years, the US FDA and regulatory agencies of certain other countries issued a notification regarding use and import of herbal products containing Aristolochia species. ${ }^{9}$

Although, detailed description of Aristolochia rotunda $\mathrm{L}$. regarding its morphology, temperament, pharmacological actions, therapeutic uses, doses, compound preparations etc are available in Unani classical literature but adequate information pertaining to its pharmacognosy, standardization, phytochemistry, quality control, therapeutic validation and toxicity studies are not available which has proved to be a limitation for presentation of data in this manuscript. However, toxicity studies carried out on aristolochic acids and their related herbal preparations and plant species have reported severe renal impairment and other toxicities including carcinomas of various organs, raised the global concern over the use of such drugs or preparations. At present, this drug is used in Unani and other alternative systems of medicine in various parts of the world due to its potential medicinal values. On this basis, the aim of present review is to highlight its various aspects as mentioned in Unani literature and in the limited studies carried out on its phytochemical, pharmacological and toxicological aspects which will ultimately guide the scholars of both traditional systems of medicine and modern scientific research to design their studies in detail on pharmacognosy, phytochemistry, standardization, quality control, therapeutic and safety evaluation, toxicity studies of every part of Aristolochia rotunda L. for further exploration.

\section{MATERIALS AND METHODS:}

In this review, 58 citations comprising Unani classical texts of Urdu and English translations, English literature on medicinal plants and published work available on PubMed, Science Direct, Springer, Research Gate and Google Scholar were referred. The classical Unani literature from the period of $9^{\text {th }}$ to $20^{\text {th }}$ Century AD were reviewed for morphology, temperament, pharmacological actions, therapeutic uses, dose, adverse reactions and their correctives, substitutes, compound formulations etc. The English books on medicinal plants from the period of 1976 to 2009 AD were reviewed for taxonomy, botanical description, pharmacological actions, habitat and geographical distribution. The published manuscripts from the period of 1999 to 2021 AD pertaining to pharmacognosy, phytochemistry, pharmacological activities, toxicology etc of Aristolochia rotunda L. were also reviewed (Table 1). The botanical names and their synonyms of plants mentioned in this paper were validated through 'The Plant List'.10 The appropriate English translations of various Unani terminologies mentioned in this manuscript were used after referring the Standard Unani Medical Terminology published by the CCRUM in collaboration with the WHO. 11

Table 1: List of reviewed literature

\begin{tabular}{|c|c|c|}
\hline Types of Literature & Title/ Source & Authors \\
\hline \multirow{13}{*}{$\begin{array}{l}\text { Unani classical } \\
\text { Literature } \\
\text { Keywords: Morphology, } \\
\text { Temperament, } \\
\text { Pharmacological actions, } \\
\text { Therapeutic uses, Dose, } \\
\text { Adverse reactions, } \\
\text { Substitute, Compound } \\
\text { formulations } \\
\text { (n = 24) }\end{array}$} & Al-Qanūnfi'l Tib (The Canon of Medicine) & Ibn Sina (980-1037 AD) \\
\hline & Kitab al-Abdal & Zakaria Razi (865-925 AD) \\
\hline & Kitab al-Mukhtarāt fi'l Tib & Ibn Hubal Al-Baghdadi (1121-1213 AD) \\
\hline & Al-Jame al-Mufredat al-Adwiyava al-Aghzia & Ibn al-Baitar (1197-1248 AD) \\
\hline & Zakhīrā Khawārizam Shahi & Ismail ibn Husayn Gorgani (1040-1136 AD) \\
\hline & $\begin{array}{l}\text { Kitab al-Fatahfi'lTadawi Man Jamee Sunufal- } \\
\text { Amrazva al-Shakawi }\end{array}$ & Abu Saeed ibn Ibrahim Al-Maghrabbi \\
\hline & Qarabadeen-i-Qadri & Akbar Arzani \\
\hline & Ilāj al-Amraz & Muhammad Shareef (1722-1807 AD) \\
\hline & Muheet-i-Azam & Azam Khan (1815-1902 AD) \\
\hline & Qarabadeen-i-Azam va Akmal & Azam Khan (1815-1902 AD) \\
\hline & Khazain al-Adwiya & Najmul Ghani (b. 1859 AD) \\
\hline & Makzan al-Mufredat & Kabeeruddin (1889-1976 AD) \\
\hline & Makhzan al-Mufredat va Murakkabat & Kabeeruddin (1889-1976 AD) \\
\hline
\end{tabular}




\begin{tabular}{|c|c|c|}
\hline & Al-Qarabaden & Kabeeruddin (1889-1976 AD) \\
\hline & Bayaz-i-Kabeer & Kabeeruddin (1889-1976 AD) \\
\hline & Qarabadeen-i-Jadeed & Abdul Hafeez \\
\hline & Hamdard Pharmacopoeia & Mohammad Said (1920-1998 AD) \\
\hline & Makhzan al-Murakkabat & Ghulam Jeelani \\
\hline & Qarabadeen-i-Sarkari & Anonymous \\
\hline & National Formulary of Unani Medicine, vol. II-VI & Anonymous \\
\hline \multirow{6}{*}{$\begin{array}{l}\text { Botanical Literature } \\
\text { Keywords: } \\
\text { Taxonomy, Botanical } \\
\text { description, } \\
\text { Pharmacological actions, } \\
\text { Habitat } \\
(\mathrm{n}=6)\end{array}$} & Standard Unani Medical terminology & Anonymous \\
\hline & Pharmacographia Indica & William Dymock \\
\hline & Materia Medica of India and Therapeutics & $\begin{array}{l}\text { Rustomjee Naserwanjee Khory, Nanabhai } \\
\text { Nawrosji Katrak }\end{array}$ \\
\hline & Indian Medicinal Plants, vol. III & K. R. Kirtikar, B. D. Basu \\
\hline & Indian Medicinal Plants & C. P. Khare \\
\hline & Pharmacognosy & C. K. Kokate, A. P. Purohit, S. B. Gokhale \\
\hline $\begin{array}{l}\text { Published articles } \\
\text { Keywords: } \\
\text { Pharmacognosy, } \\
\text { Toxicolology, } \\
\text { Phytochemistry, } \\
\text { Pharmacological } \\
\text { activities (n = 28) }\end{array}$ & \multicolumn{2}{|c|}{ PubMed, Science Direct, Springer, Research Gate and Google Scholar } \\
\hline
\end{tabular}

\section{RESULTS:}

\subsection{Scientific classification:}

Kingdom: Plantae

Subkingdom: Tracheophyte

Phylum: Spermatophyta

Subphyllum: Angiospermae

Class: Dicotyledonae

Order: Piperales

Family: Aristolochiaceae

Genus: Aristolochia

Species: $\quad$ Aristolochia rotunda L.1

3.2. Mutradifat (Vernacular names): Arabic: Zarawand Mudahraj5,12, Nukhud-i-Alward 6, Zarawand-i-Gird6,12,13, Nukhud-i-Alavandi14; $\quad$ Persian: $\quad$ Zārāwand-i-Gird ${ }^{4-6,14}$ Zarawand Mudharaj6; Isfahan: Nukhudal-Wandi, Nukhud-iMaryam; Hindi: Kajur 4,5, Zarawand Mudharaj6; Greek: Ansi2 ; English: Apple of the Earth, Mercury goosefoot, Round leaved birthwort, Smearwort; French: Aristoloche à feuillesrondes, Aristoloche arrondie, Aristoloche ronde; German: Knollige osterluzei, Rundblättrige osterluzei, Runde osterluzei, Rundknollige osterluzei; Italian: Aristolochia rotonda; Spanish: Aristoloquia redonda; Turkey: Zeravent out ${ }^{6}$; Bombay: Zaravand-i-Gird. ${ }^{14}$

\subsection{Morphology/ Botanical description:}

Etymologically, Zarawand is a Persian word which means 'golden utensil'15 in reference to the colour of roots of Aristolochia plants. In Unani medicine, it is mentioned that several branches arise directly from the root of Zarawand Mudharaj, and the length of each branch is approximately 1 balisht (9 inch). ${ }^{4}$ The leaves of Zarawand Mudharaj are small, have aromatic smell and of pungent taste than that of Zarawand Taveel, however, other macroscopic characters of leaves of both plants are same.,5 Furthermore, Ibn al-Baitar has mentioned that the leaves of Zarawand Mudharaj are round in shape and soft in touch. ${ }^{2}$ The flower is conical in shape with white and red colour. 2,4,5 Najmul Ghani states that the meaning of 'mudharaj' is round 5 which refers to the shape of root, its outer surface is yellow or golden whereas the inner surface is reddish colour.4,5,16 Most of the Unani scholars advocated that fresh roots free from insects are best for medicinal uses. ${ }^{4,5}$

According to botanical literature, Aristolochia rotunda $\mathrm{L}$. is a perennial herb growing about 2 feet in height. The species name 'rotunda' is derived from a Latin word meaning 'round' which is referred to the shape of leaf of this plant. ${ }^{1}$ The root is about 5-25 cm long, hard, horny, tuberous, placentiform 6,17 , slightly conical or rounded in shape; base compressed and broad ${ }^{14}$; more or less mamillated on the under surface and reddish-brown in colour (Fig. 1). The upper surface of the root contains remains of several small pits which represent the origin of stems while the inner surface shows one central scar marking pointed the origin of rootlets. The taste of root is bitter to some extent, aromatic with camphor like odour. Stems arising from the root are unbranched, slender and almost sessile. Leaves are obtusely heart-shaped 6,17 , stalk-less ${ }^{1}$, alternate, smooth-edged, and clasping the stem. The flowers are situated solitarily in the axils of the leaves, are tubular, outer surface is yellow and inner surface is orange brown (Fig. 2). The size of flower is approximately $2.5-5 \mathrm{~cm}$ long and flowering occurs usually during April - June. The flowers are hermaphrodite and pollinate through midges and small insects which are attracted by smell and colour of the flower.6,17 The volatiles of Aristolochia rotunda L. are slightly noticed by human nose. But it has a very specific smell to the pollinator species especially kleptoparasitic fly Chloropidae. Such flies feed on secretions from insects being killed and eaten by spiders. Aristolochia rotunda L. imitates the smell of such secretions to attract flies ${ }^{18}$ The taste of whole plant is acrid, aromatic and bitter.6,17 This medicinal plant is usually found growing in the Mediterranean regions6,19, Central Asia 6, South 


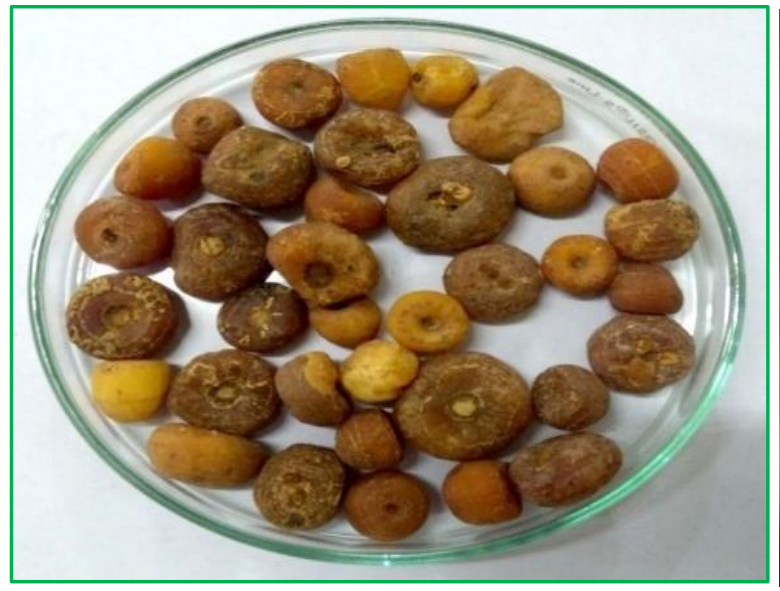

Fig. 1: Rhizome of Aristolochia rotunda L.

\subsection{Species and varieties:}

In Unani literature, different species of Zarawand have been discussed. Dioscorides (40-90 AD) has described its three varieties: (i) Zarawand Taveel, where the root is long and possesses male characteristic features; (ii) Zarawand Mudharaj whose root is round in shape and considered as female plant; (iii) The root of third variety is similar to grape wood (Chob-i-Angoor). ${ }^{3}$ Moreover, on the basis of geographical distribution, some Unani scholars depicted the varieties of Zarawand Mudharaj viz. (i). Zarawand Mudharaj Shami: A variety of Syria whose root is round and slightly conical in shape and one edge is of saffron-reddish colour; (ii). Zarawand Mudharaj Rumi: This type is indigenous to Rome whose root is not absolutely round and its edge is saffron in colour; (iii). Zarawand Mudharaj Maghribi: This is indigenous to Europe and is conical in shape. ${ }^{5}$ Taxonomically, two subspecies such as Aristolochia rotunda L. subsp. rotunda and Aristolochia rotunda L. subsp. insularis (E. Nardi \& Arrigoni) Gamisans are found in Italy and are included in its flora. ${ }^{20}$

\subsection{Mizaj (Temperament):}

According to Unani scholars, the temperament of Zarawand Mudharaj is hot-dry in 2nd stage ${ }^{4,5,16,22}$ or hot in 2nd stage \& dry in 3rd stage $3,4,5,23$ or hot-dry in 3rd stage. 4,5

\subsection{Afa'al va Istemalat (Pharmacological actions \& Therapeutic uses):}

In Unani medicine, this drug is used as muhallil (resolvent) $2,4,5,12,16$, mufatteh (deobstruent) 3,4,5,16,22, mulattif (demulscent) 2,3,4,5,12,16, jail (detergent) 2,3,4,5,16, musakkin (sedative) ${ }^{5,16}, \quad$ munaqq-i-mi'da (stomach scavenger) ${ }^{2}$, munaqq-i-seena (mucolytic \& expectorant), munaqq-i-dimag (brain scavenger) ${ }^{2,5}, \quad$ muqawwi-i-mi'da (stomachic), muqawwī-i-dimagh (brain tonic), mudirr-i-hayd (emmenagogue) ${ }^{4,5}, d \bar{a} f i^{i}-i-h u m m \bar{a}$ (antipyretic), muhallil-iawram-i-jigar va tihal (resolvent for inflammatory diseases of liver and spleen) ${ }^{5}$, dāfi'-i-ta'ffun (antimicrobial), mudammil (cicatrizant)2,5, mudirr-i-bawl (diuretic), qatil- - deedan (anthelmintic) etc . ${ }^{22}$

According to the pharmacological actions, this drug is used for the treatment of chronic pain, infections, septic wounds, pleurisy, otorrhoea, stomach disease ${ }^{4}$, hiccup, backache ${ }^{4,23}$, jaundice, chronic migraine, chronic cough, sciatica, paralysis, hip pain, leprosy, liver and uterine diseases, sexual dysfunctions 4,5 , splenomegaly, poisoning of drugs and animals $2,4,5$, chest pain, chronic headache, inflammatory

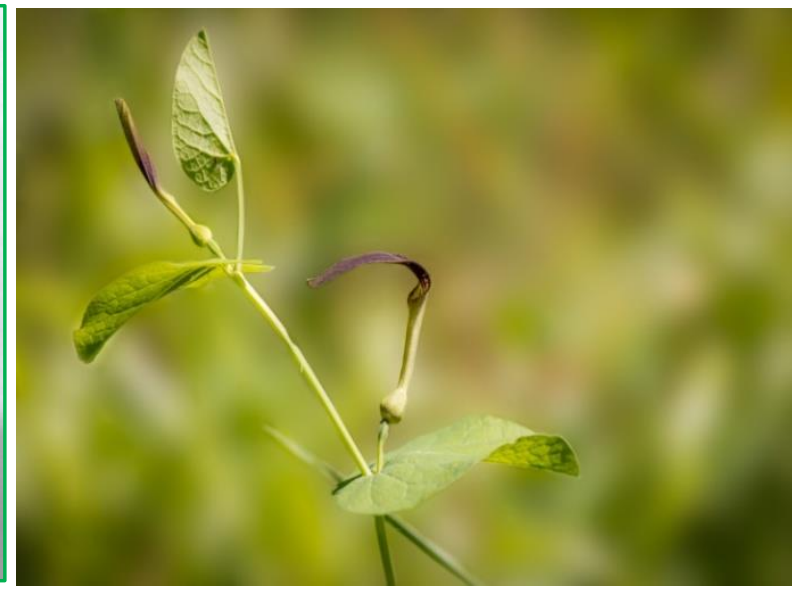

Fig. 2: Leaf \& flower of Aristolochia rotunda L.

diseases, arthritis 5 , fever, pityairisis $3,4,5$, epilepsy $2,3,4,5$, nonhealing and putrefied ulcers $2,3,4,5,23$, discoloration of teeth $^{2,3,4,5,23,24}$, asthma ${ }^{2,3,4,5,12,23}$, gout $2,3,4,12$, alopecia areata, melasma, baldness ${ }^{22}$, ascites etc .24

Apart from its use as single drug, the Unani physicians have described that this drug may be used in combination with other drugs as well. For instance, it is used in combination with Gil-i-Armani (Armenian Bole) and Babool (Acacia arabica Willd.) to enhance its astringent property. ${ }^{5}$ The paste prepared with Zarawand Mudharaj (Aristolochia rotunda Linn.), Irsa (Iris ensata Thunb.) and honey is used as an antiseptic and to promote healing of wounds. ${ }^{2,5}$ Zarawand Mudahraj along with Sikanjbeen (a formulation prepared with vinegar and honey) helps to remove morbid humours from the body. The pills or tablets prepared with the powder of Zarawand Mudahraj and ghee (3.5 g) relieve breathlessness when its smoke is inhaled.4,5 Furthermore, the paste prepared with honey is useful in hepatosplenomegaly. ${ }^{5}$ Its internal use along with honey is useful in the treatment of jaundice. ${ }^{4}$ Zarawand Mudahraj along with Murr (Commiphora myrrh (Nees) Engl.) and Filfil Siyah (Piper nigrum L.) is prescribed to eliminate morbid humours from the uterus.2,3,5 Zarawand Mudahraj along with Filfil (Piper) is useful to evacuate morbid humours from the brain and is beneficial in the treatment of epilepsy and strengthening gums. ${ }^{3}$ The liniment prepared with Zarawand Mudharaj is beneficial in the treatment of gout and sciatica. ${ }^{4}$

Apart from its uses in Unani system of medicine, it is also used in other traditional and folklore medicines as tonic diuretic, vermifuge, emmenagogue ${ }^{14}$, stomachic, stimulant and cephalic. ${ }^{6}$ This is given for the treatment of gout, jaundice, worm infestations, leprosy, itching, oliguria, anuria, oligomenorrhoea ${ }^{14}$, amenorrhoea, pectoral diseases, chronic cough, asthma etc. ${ }^{6}$ In Iranian medicine, the root of Aristolochia rotunda L. is traditionally used to treat epilepsy. 25

\subsection{Parts used and Shelf life:}

In Unani medicine, the root (rhizome) of Aristolochia rotunda $\mathrm{L}$. is medicinally used.2,4,5,12,16,26 On the basis of observations of Unani scholars, its shelf life is two years. ${ }^{4,5}$ However, it should be studied on scientific parameters as per standard guidelines.

\subsection{Authentication and Dosage:}

On the basis of observational studies, the Unani scholars asserted that Zarawand Mudahraj is adulterated with 
Zarawand Taveel by staining it with saffron which may be authenticated by immersing it in water to remove the synthetic colour. ${ }^{5}$ As per Unani literature, the therapeutic dose of Zarawand Mudharaj is 4.5 - 7 g.4,5

\subsection{Mazarrat va Muslehat (Adverse effects and Correctives):}

According to Unani physicians, the over dose or misuse of this drug may be harmful to the spleen and produces some adverse effects.4,5,16 The drugs such as Honey, Zarishk (Berberis aristata DC.), Roghan-i-Banafsha (oil of Viola odorata L.), Roghan-i-Kaddu (oil of Lagenaria siceraria (Molina) Standl.) may be used locally as well as internally to manage any adverse effects of Zarawand Mudharaj .4,5

\subsection{Badal (Substitute/ Therapeutic interchange):}

In case of non-availability of Zarawand Mudharaj, substitute drugs viz. Zaranbad (Curcuma zedoaria Rosc.) ${ }^{3-5,27}$, Bisbasa (Myristica fragrans Houtt.) ${ }^{3-5,13,23,27,}$ Qust (Saussurea lappa (Decne.) Sch.Bip.) ${ }^{3-5,13,27}$, Zarawand Taveel (Aristolochia longa L.) ${ }^{2-4,16,23}$, Rewand Chini (Rheum emodi Wall.) ${ }^{4,16}$ and Rasan (Innula racemosa Hook. f.) 4,5 may be used according to the indication.

\subsection{Murakkabat (Compound preparations):}

In Unani medicine, Zarawand Mudharaj (Aristolochia rotunda L.) has been supplemented in several compound preparations (Table 2).

Table 2: Compound preparations containing Aristolochia rotunda $\mathrm{L}$.

\begin{tabular}{|c|c|c|}
\hline Compound preparations & Therapeutic uses & Ref \\
\hline Habb-i-Istisqa $\bar{a}^{\prime}$ & Generalized oedema & 28,29 \\
\hline Qurs Hummaz & Hepatitis, Diarrhoea & 28 \\
\hline Habb-i-Atai & Productive cough, Bronchial asthma & 30 \\
\hline Laooq Zīqun Nafas Qawi & Bronchial asthma & 30 \\
\hline Majun Maddatul Hayat Jadwari & Dementia, Incontinence of urine, Arthralgia & 31 \\
\hline Dwa-i-Takore & Erectile dysfunction & 32 \\
\hline Laboob Kabeer Khaas & $\begin{array}{l}\text { Sexual dysfunction, Oligozoospermia, General body weakness, Weakness of vital } \\
\text { organs }\end{array}$ & 33 \\
\hline Sadri & Cough, Bronchial asthma & 33 \\
\hline Dawa al-Luk Kabeer & Diseases of liver, spleen and stomach, Ascites, Urolithiasis & 34 \\
\hline Roghan-i-Juntiana & Inflammation of testis, back and pelvis & 34 \\
\hline Roghan-i-Alqam & Arthralgia, Gout, Sciatica & 34 \\
\hline Qurs-i-Afsanteen & Stomach pain & 34 \\
\hline Majun Faulad & Epilepsy, Paralysis, Tremor, Sciatica, Arthritis & 34,35 \\
\hline Majun Zarawand & Cough, Bronchial asthma, Gastritis, Hepatitis & $34,35,36$ \\
\hline Majun Bolus & Dementia & 34,35 \\
\hline Anqarooya-i-Kabir & Paralysis, Epilepsy, Dementia, Sexual dysfunction, Dyspepsia, Bronchial asthma & $34,36-39$ \\
\hline Tiryaq Baleegh al-Nafa & Snake poisoning & 34 \\
\hline Habb-i-Zarawand & Generalized oedema & $29,34,36$ \\
\hline Majun Alwi Khan & Palpitation, Convulsions & $29,34,36$ \\
\hline Habb-i-Rewand & Generalized oedema, Liver disorders & 34,40 \\
\hline Tiryaq-i-Arba & $\begin{array}{l}\text { Snake, scorpion and other insects poisoning, Epilepsy, Paralysis, Diseases of liver and } \\
\text { spleen }\end{array}$ & 34,40 \\
\hline Majun Falasifa & $\begin{array}{l}\text { Sexual debility, Nerve weakness, Incontinence of urine, Arthritis, Dementia, Renal } \\
\text { pain }\end{array}$ & $16,37-40$ \\
\hline Qurs-i-Luk & Generalized oedema & 36 \\
\hline Majun Baladur & Sexual debility, General body weakness & 39 \\
\hline Marham-i-Rusul & Non-healing ulcers and wound & 39 \\
\hline Marham-i-Ushaq & Pain, Local swelling & 39 \\
\hline Habb-i-Seen & Eosinophilia, Bronchial asthma & 32,39 \\
\hline Majun Dabeedul Ward & Hepatitis, Gastritis, Metritis & 32,39 \\
\hline Majun Muruhul Arwah & Sexual dysfunction, Weakness of vital organs & $32,37-39$ \\
\hline Habb-i-Jadwar Kalan & Common cold, Rhinorrhoea, Diarrhoea & 29 \\
\hline
\end{tabular}

\subsection{Scientific studies:}

\subsubsection{Physicochemical standardization of rhizome of} Aristolochia rotund $\mathrm{L}$.

A study on physicochemical standardization of the rhizome of Aristolochia rotunda L. has reported the presence of moisture content, total ash, acid insoluble ash, water soluble ash, sulphated ash, alcohol and water-soluble extractive values as $1.29 \% \mathrm{w} / \mathrm{w}, 1.8 \%, 1.6 \%, 0.8 \%, 2 \%, 0.2 \%$ and $4.6 \%$, respectively. ${ }^{41}$

\subsubsection{Phytochemistry:}

A study has reported that some chemical constituents are found in the root of Aristolochia rotunda L. (Table 3). Amongst them, an increased concentration of aristolochic acid I and II have been observed. Aristolactams are classified as biogenic intermediates present in the biosynthetic pathway of aristolochic acids. These bioactive compounds are generally believed to produce through cyclization condensation reaction of aristolochic acids. ${ }^{42}$ The 
isoquinolones, benzyleisoquinolones alkaloids, flavonoids, ligans, biphenyl esters especially aristogins A-F, tetralones, several terpenoids \& benzenoids, steroids including $\beta$ - sitosterol and stigmasterol have also been reported in Aristolochias species. ${ }^{43}$

Table 3: Important chemical constituents of Aristolochia rotunda L.

\begin{tabular}{|l|l|l|l|}
\hline Chemical constituents & Plant part & Concentration (w/w) & Ref \\
\hline Aristolochic acid (AA) I & Root & 1.629 & 42 \\
\hline Aristolochic acid (AA) II & Root & 1.518 & 42 \\
\hline Aristolochic acid (AA) IIIa & Root & 0.159 & 42 \\
\hline Aristolochic acid (AA) IVa & Root & 0.052 & 42 \\
\hline Aristolactam (AL) I & Root & 0.005 & 42 \\
\hline
\end{tabular}

\subsubsection{Hepatoprotective activity:}

A study has reported that the hydro-alcoholic extract of rhizome of Aristolochia rotunda L. at the dose level of 89.64 $\mathrm{mg} / \mathrm{kg} \mathrm{b}$. w. significantly reduces serum bilirubin, SGOT, SGPT and ALP levels in CCl4 induced liver toxicity in albino Wistar rats. ${ }^{41}$

\subsubsection{Anti-inflammatory activity:}

The studies carried out on different bioactive compounds isolated from Aristolochia species such as aristolochic acid I, aristolochic acid IVa, aristoloctam IIIa and aristolamide II showed significant anti-inflammatory effect. 43

\subsubsection{Studies on reducing toxic effects of other drugs:}

The in vitro study has reported that aristolochic acid reduces toxic effects of prednisolone, chloramphenicol and tetracycline. ${ }^{44}$

\subsubsection{Toxicity reports:}

A case study on 'Portland's Powders', an 18th century British preparation containing Aristolochia rotunda L. used for the treatment of gout suggested that this preparation takes 20 40 years to develop chronic renal failure when it is used for long duration. This suggestion has been made based on the presence of aristolochic acid (0.15\%) in Aristolochia rotunda L. since it has been studied, that daily consumption of aristolochic acid at $1.08 \mathrm{mg}$ for the first 3 months, at $0.81 \mathrm{mg}$ for the next 3 months and at $0.54 \mathrm{mg}$ for the rest course of the treatment of gout, roughly calculated as $365 \mathrm{mg}$ is responsible for renal impairment and cancers. 45 An in-vitro cytotoxicity study of the extract of root of Aristolochia rotunda L. carried out on human kidney (HK-2) cells using sulforhodamine B (SRB) and flow cytometry-based micronucleus test (MNT) assays showed that $>200 \mu \mathrm{g} / \mathrm{ml}$ concentration possesses cytotoxicity. 46

Many patients in Belgium and Taiwan have been reported with aristolochic acid nephropathy (AAN) after using aristolochic acid containing herbal products. Moreover, the large incidence of end stage renal disease has been reported in Taiwan once. ${ }^{47}$ Cosyns et al, 1999 has reported that 10 patients out of 19 whose kidney and ureter were removed prophylactically, suffered from AAN in a Urology unit of Belgium. ${ }^{48}$ Likewise, another report of Belgium showed that 18 cases out of 39 , found urothelial cancer to be associated with aristolochic acid. ${ }^{49}$ The Therapeutic Goods Administration (TGA), an Australian authority has published a 'Practitioner Alert' in $2000 \mathrm{AD}$ in which it has been advised to health care practitioners to take extreme precautions while using any botanical product containing aristolochic acid. 50
Several studies carried out on experimental animals such as mice, rats and rabbits reported cancers of forestomach, kidney, urinary bladder, lungs etc after administration of aristolochic acid and its extract containing herbal remedies. ${ }^{51}$ The mechanisms leading to AAN are activation of p53, oxidative stress and over expression of transforming growth factor (TGF)- $\beta$. The aristolochic acid 1 and 2 have similar genotoxic and carcinogenic effects but AA1 is chiefly responsible. 46,52

Since, the carcinogenic effects of Aristolochia species manifest usually after 30 years following consumption, it could not be identified by health care professionals in early stages. It has also been reported in many recent studies that previously associated risk factors of cancers such as smoking and hepatitis result in aggravating cancers when species of Aristolochia is used concomitantly. ${ }^{46}$ Based on strong available evidences, the World Health Organization International Agency for Research on Cancer (IARC) has classified the aristolochic acids as group I carcinogenic substance. ${ }^{42}$

\section{DISCUSSION:}

Aristolochia rotunda L., an important medicinal plant which is described in Unani literature since ancient time. In Unani medicine, this potential drug has been discussed by several renowned Unani scholars such as Ibn Sina ${ }^{3}$, Ismail Gorgani ${ }^{24}$ and Zakaria Razi ${ }^{13}$ of Iran; Al-Maghrabi ${ }^{22}$ and Al-Baitar ${ }^{2}$ of Spain; Azam Khan ${ }^{4}$ and Najmul Ghani ${ }^{5}$ of India. According to origin, the Unani scholars have described its three varieties i.e., Syrian, Roman and European ${ }^{5}$ which is presently referred as common habitat of this plant. ${ }^{6}$ Most of the Unani physicians rely that the temperament of Zarawand Mudharaj is hot and dry. ${ }^{4}$ According to Unani theory, drugs act through their temperamental nature and the treatment of any disease is done on the basis of ilaj bi'l zid (heteropathy) in which drugs are used against the temperament of the disease, thereby modifying the pathological conditions. ${ }^{27}$ Owing to the temperament of this drug, it is effective as muhallil (resolvent)2,45,12,16, mufatteh (deobstruent) ${ }^{3-5,16,22}$, mulattif (demulscent) ${ }^{2-5,16}$, muqawwi-i-mi'da (stomachic), muqawwi-i-dimagh (brain tonic) ${ }^{4,5}$, muhallil-i-awram-i-zigar (resolvent for inflammatory diseases of liver) ${ }^{5}$, dāfi'-i-ta'ffun (antimicrobial) etc. 2,5 This drug is prescribed especially for the treatment of stomach disorders 4 , liver and uterine diseases 4,5 , splenomegaly etc. ${ }^{2,4,5}$ Apart from its single use, this drug is also added as an ingredient in many compound preparations of Unani medicine which are used for the treatment of various ailments. For instances, Dawa al-Luk Kabeer, Habb-i-Zarawand ${ }^{34,36}$ and Majun Dabeedul Ward ${ }^{39}$ are given for the treatment of liver diseases. Habb-iRewand $^{34,40}$ and Qurs-i-Afsanteen ${ }^{34}$ are used in treatment of 
stomach diseases. Anqarooya-i-Kabir is given for the treatment of paralysis. ${ }^{34,36,39}$ Majun Falasifa is prescribed for the treatment of neurological and kidney diseases, arthritis 39,40 and sexual dysfunctions. ${ }^{40}$

The standardization of herbal drugs includes authentication, purity and quality ${ }^{53}$ which may change due to many physical, chemical and geographical factors as well as adulteration. Although, presently, the quality of herbal drugs is a major concern for consumption, marketing them is inevitable, since nearly $80 \%$ people across the globe depend on herbs and herbal products for their health care issues. ${ }^{54}$ Various parameters such as estimation of moisture content, ash value, $\mathrm{pH}$, extractive values, microbial load, heavy metals, pesticides residue etc are applied to evaluate the quality and purity of herbal drugs. ${ }^{53}$ The moisture content in any drug should be less in order to prevent microbial contamination. The range between $10-20 \%$ showed less chance of bacterial and fungal growth. The ash value is an imperative parameter to detect adulterants and to confirm the purity of any drug. 55 Extractive values determine the presence of the active constituents ${ }^{56}$ and further indicates the quality and purity of the drug. ${ }^{57} \mathrm{~A}$ less extractive value in any plant drug may be due to exhausted material, adulteration, improper drying and storage. ${ }^{58}$ In a physicochemical standardization study, the moisture content, total ash, acid insoluble ash, water soluble ash and sulphated ash values of rhizome of Aristolochia rotunda L. were found to be within normal range which shows the purity of the sample. In addition, the water-soluble extractive value was found to be more than alcohol soluble extractive value which shows more solubility of the rhizome in water. The significant hepatoprotective effect of the hydro-alcoholic extract of rhizome of Aristolochia rotunda $\mathrm{L}$. in an animal model ${ }^{51}$ validated the claim of Unani physicians since this drug is preferably used for the treatment of liver disorders.4,5,24 Toxicity studies carried out on Aristolochia rotunda L. and its bioactive constituents and several reports of patients who consumed aristolochic acids containing herbal preparations have reported nephropathy and carcinomas of various organs. ${ }^{46}$ In Unani medicine, Aristolochia rotunda L. is used for short period for therapeutic purposes. In spite of drug reported serious toxic effects, the benefit of the drug outweighs the risk. But, in view of such reports, further studies to evaluate the safety profile of all Aristolochia species including Aristolochia rotunda L. should be carried out. 46

The present review has suggested that the pharmacognostical studies of parts of Aristolochia rotunda L. such as leaf, flower, stem, rhizome etc may be carried out through organoleptic and microscopic evaluation. In addition, physicochemical standardization of leaf, flower and stem such as moisture content; total ash, water soluble ash, acid insoluble ash and sulphated ash values; $\mathrm{pH}$, identification of foreign organic matters, extractive values in different solvents; and quality control studies of these parts including rhizome such as microbial load, pesticides residue, presence of aflatoxins, heavy metal analysis may also be carried out. Since, secondary metabolites of plant materials such as alkaloids, glycosides, flavonoids, saponins, tannins etc are important to know the pharmacological effects ${ }^{54}$, a detailed qualitative and quantitative analysis of rhizome and other parts of Aristolochia rotunda L. may be studied by using modern analytical tools such as Ultraviolet and Infrared Spectroscopy, High Performance Thin Layer Chromatography (HPTLC), High Performance Liquid Chromatography (HPLC), Liquid Chromatography-Mass Spectroscopy (LC-MS), Gas Chromatography-Mass Spectroscopy (GC-MS), Inductively Coupled Plasma-Mass Spectroscopy (ICP-MS) etc. ${ }^{4}$ These parameters will be useful for authentication and standardization of Aristolochia rotunda L. Furthermore, except hepatoprotective study of rhizome of Aristolochia rotunda L. in an animal model, other pharmacological properties of this drug have not been validated yet, either through pre-clinical and clinical studies which are also required for further exploration.

\section{CONCLUSION:}

On perusal of various classical Unani and other related literature, it was found that Zarawand Mudharaj (Aristolochia rotunda L.) is widely used in Unani medicine for the treatment of several ailments particularly liver and stomach disorders. Apart from therapeutic uses, Unani scholars have also mentioned other aspects of this plant drug such as botanical morphology, temperament, different varieties according to their habitat, shelf-life and adverse effects and their correctives on the basis of observational studies, and appropriate substitutes etc. Only limited information regarding pharmacognostical evaluation, physicochemical standardization, quality control, phytochemical analysis, pharmacological activities and toxicological studies of this drug is available in the public domain which warrants it imperative that these studies may be carried out on scientific lines for understanding its immense benefits profoundly.

\section{Funding Source:}

This research did not receive any specific grant from funding agencies in the public, commercial, or not-for-profit sectors.

\section{Conflict of interest:}

All the authors have confirmed that there are no known conflicts of interest associated with this publication and there has been no significant financial support for this work that could have influenced its outcome.

\section{Author Contribution:}

Athar Parvez Ansari: Performed the literature survey and collected most of the reference, compiled and drafted the manuscript. Huzaifa Ansari \& Ifra Qayoom: Collected some of the references which are referred in this manuscript. Tariq Ahmad Butt: Edited the manuscript especially botanical part of the drug. IN. Zaheer Ahmed: Critically reviewed and edited whole manuscript.

\section{References}

1. Aristolochia rotundar Available from https://en.wikipedia.org/wiki/Aristolochiarotunda [Accessed 20 June 2020].

2. Al-Baitar. Al Jame al-Mufradat al-Adwiya va al-Aghzia, $2^{\text {nd }}$ vol. (Urdu translation by CCRUM). New Delhi: Central Council for Research in Unani Medicine, Dept. of AYUSH, Ministry of Health \& Family Welfare, Govt. of India; 2000: p. 333-335.

3. Sina I. Al Qanoon fi al-Tib, $2^{\text {nd }}$ vol. (Urdu translation by Kantoori GH). New Delhi: Aijaz Publishing House; 2010: p. 338-339.

4. Khan MA. Muheet-i-Azam, $2^{\text {nd }}$ vol. (Urdu translation by CCRUM). New Delhi: Central Council for Research in Unani Medicine, Central Council for Research in Unani Medicine, Dept. of AYUSH, Ministry of Health \& Family Welfare, Govt. of India; 2013; p. 754-756

5. Khan NG. Khazain al-Adwiya, $4^{\text {th }}$ vol. New Delhi: Central Council for Research in Unani Medicine, Central Council for Research in Unani Medicine, Dept. of AYUSH, Ministry of Health \& Family Welfare, Govt. of India; 2010; p. 253-254.

6. Akbar S. Aristolochia rotunda L. (Aristolochiaceae). In: Handbook of 200 medicinal plants. Springer, Cham. 2020. https://doi.org/10.1007/978-3-030-16807-033. 
7. Kuo PC, Li YC, Wu TS. Chemical constituents and pharmacology of the Aristolochia species. J. Tradit. Complement. Med. 2012; 2 (4): 249-266. doi: 10.1016/s2225-4110 (16) 30111-0. https://doi.org/10.1016/S2225-4110(16)30111-0

8. Han J, Xian J, Jhang Y, Liu J, Liang A. Systemic overview of Aristolochic acids: Nephrotoxicity, Carcinogenicity and underlying mechanism. Front. Pharmacol. 2019. 10.648. doi: 10.3389/fphar.2019.00648.

https://doi.org/10.3389/fphar.2019.00648

9. Yang HY, Chen PC, Wang, JD. Chinese Herbs Containing Aristolochic acid associated with renal failure and urothelial carcinoma: A review from epidemiologic observations to causal inference. Bio Med Research International. 2014 http://dx.doi.org/10.1155/2014/569325.

10. The Plant List. Available from: www.theplantlist.org. [Accessed 04 June 2021].

11. Anonymous. Standard Unani Medical Terminology. New Delhi: CCRUM, Dept. of AYUSH, Ministry of Health \& Family Welfare, Govt. of India; 2012: p. 1-374.

12. Anonymous. Makhzan al-Mufredat va Murakkabat. New Delhi: Central Council for Research in Unani Medicine, Dept. of AYUSH Ministry of Health \& Family Welfare, Govt. of India; 2007: p. 137.

13. Razi AMZ. Kitab al-Abdal, $3^{\text {rd }}$ ed. (Urdu translation by CCRUM) New Delhi: Central Council for Research in Unani Medicine, Ministry of H \& FW, Govt. of India; 2000: p. 75.

14. Khory RN, Katrak NN. Materia Medica of India and their therapeutics. Delhi: Neeraj Publishing House; 1985: p. 514.

15. Sana SH. A comprehensive review of the pharmacological potential of Aristolochia longa Linn. European Journal of Pharmaceutical and Medical Research. 2020; 7 (8):366-368.

16. Kabeeruddin M. Makhzan al-Mufredat, $3^{\text {rd }}$ ed. IdaraKitab alShifa, New Delhi. 2014: p. 312-313.

17. Dymock, W, Warden CJH, Hooper D. Pharmacographia India, Part III. New Delhi: Sristi Book Distributors; 1976: p. 399-403.

18. Gross M. Could plants have cognitive abilities? Current Biology. 2016; 26 (5): R181-R191. doi: 10.1016/j.cub.2016.02.044 https://doi.org/10.1016/j.cub.2016.02.044

19. Oelschlagel B, Nuss M, Tschirnhaus MV, Patzold C, Neinhuis C, Dotterl S, Wanke S. The betrayed thief- the extraordinary strategy of Aristolochia rotunda to deceive its pollinators. New Phytologist. 2014. doi: 10.1111/nph.13210. https://doi.org/10.1111/nph.13210

20. Kirtikar KR, Basu BD. Indian Medicinal Plants. $3^{\text {rd }}$ vol. Delhi: Periodical Experts Book Agency; 2005: p. 2121.

21. Bartoluccia F, Peruzzi L, Galasso G, Albano A, Alessandrini A Ardenghi NMG, et al. An updated checklist of the vascular flora native to Italy. Plant Biosystems - An International Journal Dealing with all Aspects of Plant Biology. 2018; 152 (2): 179183. https://doi.org/10.1080/11263504.2017.1419996.

22. Al-Maghrabi AS. Kitab al-Fatah fi al-Altadawi Min JameeSanuf alAmrazva al-Shakawi, $1^{\text {st }}$ ed (Urdu translation by Bari A). Delhi: NCPC Printers; 2007: p. 102-103.

23. Al-Hubal I. Kitab al-Mukhtarat fi al-Tib, $2^{\text {nd }}$ vol. (Urdu translation by CCRUM). New Delhi: Central Council for Research in Unani Medicine, Dept. AYUSH, Ministry of Health \& Family Welfare. Govt. of India; 2005: p. 125-126.

24. Gorgani AH. ZakhiraKhawarizm Shahi, $10^{\text {th }}$ vol. (Urdu translation by Khan $\mathrm{HH}$ ). New Delhi: Idarah Kitab al-Shifa; 2010: p. 17, 32.

25. Sharanavard S, Ghafari S, Mosaddegh M. Medicinal plants used in Iranian traditional medicine to treat epilepsy. Seizure. 2014; 23: 328-32. http://dx.doi.org/10.1016/j.seizure.2014.01.013.

26. Anonymous. Qarabadeen-i-Sarkari (Urdu translation by CCRUM). New Delhi: Central Council for Research in Unani
Medicine, Ministry of Health \& Family Welfare, Govt. of India; 2006: p. 77.

27. Ansari AP, Sana SH, Ansari H. The concept of Abdal-i-Adwiya (drug substitution/ therapeutic interchange) in Unani medicine: A critical appraisal. Journal of Advanced Research in Pharmaceutical Sciences and Pharmacology Interventions. 2020; 3 (1): 1-11.

28. Anonymous. National Formulary of Unani Medicine. Part II. $1^{\text {s }}$ vol. New Delhi: Dept. of AYUSH, Ministry of Health \& Family Welfare, Govt. of India; 2007: p. 13, 30.

29. Khan MA. Qarabadeen-i-Azam va Akmal. New Delhi: Central Council for Research in Unani Medicine, Dept. of AYUSH, Ministry of Health \& Family Welfare, Govt. of India; 2005: p. 43 57,458 .

30. Anonymous. National Formulary of Unani Medicine. Part III. $1^{\text {s }}$ ed. New Delhi: Dept. of AYUSH, Ministry of Health \& Family Welfare, Govt. of India; 2001: p. 10, 87.

31. Anonymous. National Formulary of Unani Medicine. Part IV. $1^{\text {st }}$ ed. New Delhi: Dept. of AYUSH, Ministry of Health \& Family Welfare, Govt. of India; 2006: p. 52.

32. Anonymous. National Formulary of Unani Medicine. Part V. New Delhi: Dept. of AYUSH, Ministry of Health \& Family Welfare, Govt. of India; 2008: p. 16, 90-91, 95-98, 151.

33. Anonymous. National Formulary of Unani Medicine. Part VI. New Delhi: Dept. of AYUSH, Ministry of Health \& Family Welfare, Govt. of India; 2011: p. 60-61, 67-69.

34. Kabeeruddin M. Al-Qarabadeen, $2^{\text {nd }}$ ed. New Delhi: Central Council for Research in Unani Medicine, Dept. of AYUSH, Ministry of Health \& Family Welfare. Govt. of India; 2006: p. 23, $57,157,159,339,459,460,913,1134,1143,1150,1154$.

35. Khan MS. 'Ilāj al-Amraz (Urdu translation by Kabeeruddin M) New Delhi: Aijaz Publishing House; 2006: p. 119, 120, 288.

36. Arzani MA. Qarabadeen-i-Qadri (Urdu translation by CCRUM) New Delhi: Central Council for Research in Unani Medicine, Ministry of Health \& Family Welfare, Govt. of India; 2009: p.17, $88,375,385,413$.

37. Kabeeruddin M. Bayaz-i-Kabeer, $2^{\text {nd }}$ vol. New Delhi: Central Council for Research in Unani Medicine, Dept. of AYUSH, Ministry of Health \& Family Welfare, Govt. of India; 2008: p. 15, $189,193$.

38. Hafeez A. Qarabadeen-i-Jadeed. New Delhi: Central Council for Research in Unani Medicine, Dept. of AYUSH, Ministry of Health \& Family Welfare, Govt. of India; 2005: p. 16, 212, 216.

39. Said M. Hamdard Pharmacopoeia of Eastern Medicine, $2^{\text {nd }}$ ed Delhi: Sri Satguru Publications; p. 1997: 73, 105, 254, 256, 261 269-270,278, 283-284.

40. Jeelani G. Makhzan al-Murakkabat. New Delhi: Aijaz Publishing House; 1995: p. 27, 68, 356.

41. Ansari AP, Sana SH, Dar MY, Goswami P, Ahmed ZN. Validation of Unani concept of Abdāl-i-Adwiya (Drug substitution) by physicochemical standardization and hepatoprotective activity of Aristolochia rotunda Linn. and its substitute Curcuma zedoaria Rosc. in albino Wistar rats. J. Complement. Integr. Med. 2021. https://doi.org/10.1515/jcim-2020-0378.

42. Han J, Xian J, Jhang Y, Liu J, Liang A. Systemic overview of Aristolochic acids: Nephrotoxicity, Carcinogenicity and underlying mechanism. Front. Pharmacol. 2019. 10.648. doi: https://doi.org/10.3389/fphar.2019.00648.

43. Kuo PC, Li YC, Wu TS. Chemical constituents and pharmacology of the Aristolochia species. J. Tradit. Complement. Med. 2012; 2 (4): 249-66. doi: https://doi.org/10.1016/s2225-4110 (16) 30111-0.

44. Khare CP. Indian Medicinal Plants. Berlin: Springer Science + Business Media, LLC. 2007: p. 62. https://doi.org/10.1007/978 0-387-70638-2 
45. Tomlinson T, Fernandes A, Grollman AP. Aristolochia Herbs and Iatrogenic Disease: The Case of Portland's Powders. Yale J Biol Med. 2020: 93, 355-363.

46. Michl J, Kite GC, Wanke S, Zierau O, Vollmer G, Neinhuis C, et al. LC-MS- and ${ }^{1} \mathrm{H}$ NMR based metabolic analysis and in vitro toxicological assessment of 43 Aristolochia species. J. Nat. Prod. 2016; 79: 30-37. doi: https://doi.org/10.1021/acs.jnatprod.5b00556

47. Yang HY, Chen PC, Wang, JD. Chinese Herbs Containing Aristolochic acid associated with renal failure and urothelial carcinoma: A review from epidemiologic observations to causal inference. Bio Med Research International. 2014. http://dx.doi.org/10.1155/2014/569325.

48. Cosyns JP, Jadoul M, Squiflett JP, Wese FX, van Ypersele de Strihou C, et al. Urothelial lesions in Chinese-herb nephropathy. Am. J. Kidney Dis. 1999; 33: 1011-1017. doi: http://dx.doi.org/10.1016/S0272-6386(99)70136-8 .

49. Nortier JL, Martinez MC, Schmeiser HH. Arlt VM, Bieler CA, Petein $\mathrm{M}$, et al. Urothelial carcinoma associated with the use of a Chinese herb (Aristolochia fangchi). N. Engl. J. Med. 2000; 342: 1686-1692. doi: http://dx.doi.org/10.1056/NEJM/200006083422301

50. Practitioner Alert. Therapeutic Goods Administration. Australia. 1-9. 2000. Available from: www.http://centerforinquiry.org [Accessed 18 August 2021].

51. Plants containing aristolochic acids. IARC Monographs- $100 \mathrm{~A}$. Available from: www.http://monographs.iarc.fr [Accessed 18 August 2021].
52. Prevention of drug-associated risks, Stage II. Medicinal products manufactured using plants of the Aristolochiaceae family with the genera Asarum, Aristolochia, Saruma and Thottea. Available from: https://www.bfarm.de [Accessed 27 May 2021].

53. Patwekar SL, Suryawanshi AB, Gaikwad MS, Snehal PR, Potulwar AP. Standardization of herbal drugs: An overview. The Pharma Innovation Journal. 2015; 4 (9): 100-104.

54. Balekundri A, Mannur V. Quality control of the traditional herbs and herbal products: A review. Future J. Pharm. Sci. 2020; 6 (67). http://doi.org/10.1186/s43094-020-00091-5 .

55. Sabiha S, Aftab A, Asif M, Akhtar M, Saud I. Physicochemical and phytochemical standardization of berries of Myrtus communis Linn. J Pharm Bioallied Sci. 2012; 4 (4): 2012: 322326. doi: http://dx.doi.org/10.4103/0975-7406.103266

56. Kokate CK, Purohit AP, Gokhale SB. Pharmacognosy, 43 ${ }^{\text {rd }}$ ed. Mumbai: Nirali Prakashan; 2009: p. 6.20.

57. Patil AG, Koli SP, Patil DA, Phatak AV. Evaluation of extraction techniques with various solvents to determine extraction efficiency of selected medicinal plants. Int. J. Pharm. Sci. Res. 2012; 3 (8): 2607-2612. http://dx.doi.org/10.13040/IJPSR.0975-8232.3.

58. Chandel HS, Pathak AK, Tailang M. Standardization of some herbal antidiabetic drugs in polyherbal formulation. Pharmacogn. Res. 2011; 3 (1): 49-56. doi: http://dx.doi.org/10.4103/0974-8490.79116 